\title{
Oil Palm (Elaeis guineensis) Responses to Indigenous Mycorrhizae and Cow Manure in Ultisol
}

\author{
DOI: 10.18196/pt.2019.099.103-109
}

\author{
Elis Kartika*, Made Deviani Duaja, Gusniwati \\ Department of Agroecotechnology, Faculty of Agriculture, University of Jambi, \\ Jl. Raya Jambi - Muara Bulian KM 15, Mendalo Indah, Jambi, Indonesia \\ ${ }^{*}$ Corresponding author, email: elisk63@yahoo.com
}

\begin{abstract}
The experiment was conducted to examine the effects of indigenous mycorrhizae inoculation and cow manure doses on the growth and yield of oil palm (Elaeis guineensis) at production stages I. It was conducted at farmer plantation in Semabu Village Tebo Regency located at -1.473543, 102484062. This research was arranged in a randomized block design consisting of two factors. The first factor is inoculation of mycorrhizae isolates comprising two levels, i.e. without and with inoculation, and the second factor is the dose of cow manure comprising five levels, i.e. without cow manure, 25\%, 50\%, 75\%, and $100 \%$ of the recommended dose of cow manure at Production Stages I (30 kg plant-1). The variables observed were plants girth, leaf midrib, number of bunches per plant, weight per bunch, weight of fresh fruit bunches per plant, and root infection. The results showed that there was interaction effect between inoculation of mycorrhizae and cow manure doses. The inoculation of mycorrhizae and cow manure at a dose of $50 \%$ of the recommended dose were able to increase oil palm growth and yield.
\end{abstract}

Keywords: Cow manure, Inoculated, Mycorrhizae, Oil palm, Ultisol

\section{ABSTRAK}

Tujuan dari penelitian ini adalah untuk mempelajari pengaruh inokulasi mikoriza indigenus dan pupuk kandang kotoran sapi terhadap pertumbuhan dan hasil kelapa sawit (Elaeis guineensis) pada Tanaman Menghasilkan tahun pertama (TM I). Penelitian ini dilakukan di kebun petani di Desa Semabu Kabupaten Tebo (lokasi - 1.473543, 102484062). Percobaan ini menggunakan Rancangan Acak Kelompok dengan 2 faktor. Faktor pertama adalah isolat mikoriza indigenus yang terdiri dari dua level yaitu tanpa inokulasi dan inokulasi mikoriza, and faktor kedua adalah dosis pupuk kandang kotoran sapi yang terdiri dari lima level yaitu tanpa pupuk kandang kotoran sapi, 7.5, 50, 75, and 100 \% dosis rekomendasi pupuk kandang kototan sapi untuk TM I (30 Kg tanaman-1). Variabel yang diamati yaitu lingkar batang, jumlah pelepah, jumlah tandan per tanaman, bobot buah per tandan, bobot tandan buah segar per tanaman dan infeksi akar Hasil penelitian menunjukkan bahwa terjadi interaksi antara inokulasi mikoriza indigenus dan dosis pupuk kandang kotoran sapi. Inokulasi mikoriza indigenus dan pupuk kompos kotoran sapi 50\% dari dosis yang direkomendasikan mampu meningkatkan pertumbuhan dan hasil kelapa sawit.

Kata Kunci: Pupuk kendang, Inokulasi, Mikoriza, Kelapa sawit, Ultiso

\section{INTRODUCTION}

The global demand for oil palm is continuously increasing due to the population increase and oil palm diversification by the producer. Hence, oil palm production has good prospects to be developed in Indonesia. The production of oil palm production could be increased through several ways such as area expansion, intensification and rehabilitation programs. In Jambi Province, the main problem in expanding oil palm plantation is the limited availability of fertile land. Mostly, the land in Jambi is composed of infertile soil Ultisol. Ultisol is known as marginal soil that has low fertility, shallow solum, low water holding capacity, One of the efforts to overcome the problem is the application of indigenous mycorrhizae fungi that could help plants uptake nutrients. Furthermore, the application could be accompanied with the addition of organic material from cow manure to optimize the function of mycorrhizae in plant.

The application of mycorrhizae in plants has been widely proven to be able to improve nutrient and water absorption and to promote plant growth. Nutrients uptake, especially $P$, is improved in plants infected by mycorrhizae. As it is known, $\mathrm{P}$ is largely required by plants despite its limited availability in soils nutrient. A research by Kartika (2012) showed vulnerability to erosion, low $\mathrm{pH}$, and high $\mathrm{Al}$ levels. the water use of oil palm seedlings inoculated with 
mycorrhizae was more efficient compared to the ones without mycorrhizae. The effect of mycorrhizae on ultisol will be more optimal if combined with organic material. According to Tampubolon and Hendriansyah (2011), organic material from cow manure can improve physical, chemical, and biological properties of the soil. For those reasons, the purpose of this research was to determine the oil palm responses to the mycorrhizae inoculation and cow manure doses.

\section{MATERIALS AND METHODS}

This experiment was conducted in land with ultisol soil in Semabu village, Tebo Regency located at $-1.473543,102484062$. The experiment was arranged in Randomized Complete Block Design, consisting of two factors and four replications. The first factor is mycorrhizae inoculation (without and with inoculation of indigenous mycorrhizal Glomus sp-16). Indigenous mycorrhizal Glomus sp-16 is an indigenous mycorrhizal isolate from marginal land in Tebo Regency, cultured at Teaching and Research Farm, Faculty of Agriculture, Jambi University (Kartika, et al., 2010). The second factor is the dose of organic fertilizer (without cow manure (0\%) and with cow manure at 5, 50, 75, and 100 $\%$ of the recommended dose $\left(30 \mathrm{~kg}\right.$ plant $\left.{ }^{-1}\right)$ ). Cow manure was fermented four weeks until composted perfectly, and it was characterized from the texture, which is crumbly, dry, cold and odorless. The nutrient contents of cow manure were Carbon 28.11 $\%$, Nitrogen $1.98 \%, \mathrm{C} / \mathrm{N}$ ratio $14, \mathrm{P}_{2} \mathrm{O}_{5} 805 \mathrm{ppm}$, and $\mathrm{K}_{2} \mathrm{O} 468$ ppm.

Oil palm cv. Tenera at the age of 12 months was used in this study. In the field, the plants were arranged with spacing of $9 \times 9 \mathrm{~m}$ and planting holes of $30 \times 30 \times 30 \mathrm{~cm}$. Three months before transplanted to the field, the plants were inoculated with mycorrhizae according to the treatments. Meanwhile, the cow manure treatment was applied to the field seven days before planting time. Two plants from each plot were randomly selected and tagged for observation. The variables observed included plants girth, number of leaf midribs, number of bunches per plant, weight of fresh fruit bunches per plant and root infection. Plants girth was measured at a height of $5 \mathrm{~cm}$ from the base of the stem, leaf midrib number was calculated by counting all the midribs which opened perfectly and fresh, bunch number per plant was calculated by counting all bunches formed in one plant, fruit weight per bunch was weight of all fruits in one bunch, fresh fruit bunches weight was measured all fresh fruit bunches (FFB) per plant at harvest, and root infection was carried out on the roots of sample plants based on root staining techniques according to the method of Kormanik and McGraw (1982). The collected data were subjected to standard statistical analysis by Steel and Torrie (1980), followed by DMRT at $\alpha=5 \%$.

\section{RESULTS AND DISCUSSION}

Plants Girth

The results showed that there was interaction effect between mycorrhizae inoculation and cow manure doses on the plants girth. The highest plants girth was observed in the plants treated with mycorrhiza inoculation and cow manure at a dose of $50 \%$ of recommended dose (Table 1 ).

\section{Number of Leaf Midrib}

The results showed that there were interaction effects between mycorrhizae inoculation and cow manure doses on the number of leaf midrib. The plants treated with mycorrhizae inoculation and cow manure doses of $75 \%$ had significantly higher number of leaf midrib compared to the plants treated without mycorrhizae inoculation and without cow manure $(0 \%)$ (Table 2$)$. 
Table 1. Plants Girth as Affected by Mycorrhizae Inoculation and Cow Manure Doses

\begin{tabular}{|c|c|c|c|c|c|c|}
\hline \multirow{2}{*}{ Mycorrhizae } & \multicolumn{5}{|c|}{ Cow manure (percentage of recommended doses fertilizer for oil palm) } & \multirow{2}{*}{ Mean } \\
\hline & 0 & 25 & 50 & 75 & 100 & \\
\hline Without inoculation & $\begin{array}{c}64 b \\
A\end{array}$ & $\begin{array}{c}67.50 a b \\
A\end{array}$ & $\begin{array}{c}68.33 a b \\
B\end{array}$ & $\begin{array}{c}68.00 a b \\
B\end{array}$ & $\begin{array}{c}72.83 \text { a } \\
\text { B }\end{array}$ & $\begin{array}{c}68.13 \\
B\end{array}$ \\
\hline With inoculation & $\begin{array}{c}67.83 \mathrm{C} \\
\mathrm{A}\end{array}$ & $\begin{array}{c}73.67 \text { bc } \\
A\end{array}$ & $\begin{array}{c}80.83 a \\
A\end{array}$ & $\begin{array}{c}79.00 a b \\
A\end{array}$ & $\begin{array}{c}79.67 a b \\
A\end{array}$ & $\begin{array}{c}76.20 \\
\text { A }\end{array}$ \\
\hline Mean & $65.92 b$ & $70.58 a b$ & 74.58 a & $73.50 \mathrm{a}$ & $76.25 a$ & \\
\hline
\end{tabular}

Remarks: Means followed by the same uppercase letter in the same column and by the same lowercase letter in the same row are not significantly different according to DMRT at $5 \%$. Recommended dose of organic fertilizer (cow manure): $30 \mathrm{~kg} \mathrm{plant}^{-1}$

Table 2. The Number of Leaf Midrib as Affected by Mycorrhizae Inoculation and Cow Manure Doses

\begin{tabular}{|c|c|c|c|c|c|c|}
\hline \multirow{2}{*}{ Mycorrhizae } & \multicolumn{5}{|c|}{ Cow manure (percentage of recommended doses fertilizer for oil palm) } & \multirow{2}{*}{ Mean } \\
\hline & 0 & 25 & 50 & 75 & 100 & \\
\hline Without inoculation & $\begin{array}{c}36.67 \mathrm{~b} \\
\text { B }\end{array}$ & $\begin{array}{c}42.00 \mathrm{a} \\
\mathrm{A}\end{array}$ & $\begin{array}{c}42.17 a \\
A\end{array}$ & $\begin{array}{c}43.00 \mathrm{a} \\
\mathrm{A}\end{array}$ & $\begin{array}{c}43.33 \mathrm{a} \\
\mathrm{A}\end{array}$ & $\begin{array}{c}41.43 \\
\text { A }\end{array}$ \\
\hline With inoculation & $\begin{array}{c}42.50 \mathrm{a} \\
\mathrm{A}\end{array}$ & $\begin{array}{c}41.00 \mathrm{a} \\
\mathrm{A}\end{array}$ & $\begin{array}{c}43.50 \mathrm{a} \\
\mathrm{A}\end{array}$ & $\begin{array}{c}44.00 \mathrm{a} \\
\mathrm{A}\end{array}$ & $\begin{array}{c}43.83 \mathrm{a} \\
\mathrm{A}\end{array}$ & $\begin{array}{c}42.97 \\
\text { A }\end{array}$ \\
\hline Mean & $39.58 \mathrm{a}$ & $41.50 \mathrm{a}$ & $42.83 \mathrm{a}$ & $43.50 \mathrm{a}$ & $43.58 \mathrm{a}$ & \\
\hline
\end{tabular}

Number of Bunches per Plant

The results showed that there were interaction effects between mycorrhizae inoculation and cow manure doses on the number of bunches per plant. The highest number was obtained int the plants treated with mycorrhizae inoculation and cow manure doses of $50 \%$ of recommended dose (Table 3 ).

\section{Fruit Weight per Bunch}

The results showed that there were no interaction effects between mycorrhizae inoculation and cow manure doses on fruit weight per bunch. However, there was a tendency that the highest fruit weight per bunch was achieved in the plants treated with mycorrhizae inoculation and cow manure doses of $50 \%$ of recommended dose.

\section{Fresh Fruit Bunches Weight per Plant}

The results showed that there were interaction effects between mycorrhizae inoculation and cow manure doses on the weight of fresh fruit bunches per plant. The highest value was obtained in the plants treated with mycorrhizae inoculation and cow manure doses of $50 \%$ of recommended doses (Tabel.5)

\section{Root Infection}

Data in Table 6 showed that the plants inoculated with mycorrhizae had high percentage of root infections. Meanwhile, slight root infection was also observed in the plants that were not inoculated with mycorrhizae. This result showed that even though the plants were not inoculated with mycorrhizae, however, there were local mycorrhizae (natural mycorrhizae) in the field that could infect the roots. High root infection will help plants absorb nutrients, especially phosphate.

The highest values of plants girth, number of bunches, fruit weight per bunches and fresh fruit bunches weight per plant were obtained in the plants treated with with mycorrhizae inoculation and cow manure at a dose of $50 \%$ of the recommended dose (Table 1, Table 3, Table 4 and Table 5). It means that the application of cow manure at a dose of $50 \%$ of the recommended dose and 
Table 3. The Number of Bunches Per Plant as Affected by Mycorrhizae Inoculation and Cow Manure Doses

\begin{tabular}{|c|c|c|c|c|c|c|}
\hline \multirow{2}{*}{ Mycorrhizae } & \multicolumn{5}{|c|}{ Cow manure (percentage of recommended doses fertilizer for oil palm) } & \multirow{2}{*}{ Mear } \\
\hline & 0 & 25 & 50 & 75 & 100 & \\
\hline Without inoculation & $\begin{array}{c}19.22 b \\
A\end{array}$ & $\begin{array}{c}15.33 c \\
B\end{array}$ & $\begin{array}{c}15.17 \mathrm{C} \\
\mathrm{B}\end{array}$ & $\begin{array}{c}22.28 \\
A\end{array}$ & $\begin{array}{c}21.89 a b \\
A\end{array}$ & $\begin{array}{c}18.78 \\
B\end{array}$ \\
\hline With inoculation & $\begin{array}{c}14.72 \mathrm{~d} \\
B\end{array}$ & $\begin{array}{c}19.17 \text { c } \\
A\end{array}$ & $\begin{array}{c}24.44 a \\
A\end{array}$ & $\begin{array}{c}23.89 a b \\
A\end{array}$ & $\begin{array}{c}21.28 b c \\
A\end{array}$ & $\begin{array}{c}20.70 \\
A\end{array}$ \\
\hline Mean & $16.97 d$ & $17.25 \mathrm{~cd}$ & $19.81 b c$ & $23.08 a$ & $21.58 a b$ & \\
\hline
\end{tabular}

Remarks: Means followed by the same uppercase letter in the same column and by the same lowercase letter in the same row are not significantly different according to DMRT at 5\%. Recommended dose of organic fertilizer (cow manure): $30 \mathrm{~kg} \mathrm{plant}^{-1}$

Table 4. The Weight of Fruit Per Bunch as Affected by Mycorrhizae Inoculation and Cow Manure Doses

\begin{tabular}{|c|c|c|c|c|c|c|}
\hline \multirow{2}{*}{ Mycorrhizae } & \multicolumn{5}{|c|}{ Cow manure (percentage of recommended doses fertilizer for oil palm) } & \multirow{2}{*}{ Mear } \\
\hline & 0 & 25 & 50 & 75 & 100 & \\
\hline Without inoculation & $\begin{array}{c}3.86 a \\
A\end{array}$ & $\begin{array}{c}3.92 \mathrm{a} \\
\mathrm{A}\end{array}$ & $\begin{array}{c}3.90 \mathrm{a} \\
\mathrm{A}\end{array}$ & $\begin{array}{c}3.93 a \\
A\end{array}$ & $\begin{array}{c}4.03 a \\
A\end{array}$ & $\begin{array}{c}3.93 \\
A\end{array}$ \\
\hline With inoculation & $\begin{array}{c}3.94 a \\
\text { A }\end{array}$ & $\begin{array}{c}3.93 a \\
\text { A }\end{array}$ & $\begin{array}{c}4.20 \mathrm{a} \\
\mathrm{A}\end{array}$ & $\begin{array}{c}4.17 \mathrm{a} \\
\mathrm{A}\end{array}$ & $\begin{array}{c}4.16 a \\
A\end{array}$ & $\begin{array}{c}4.08 \\
A\end{array}$ \\
\hline Mean & $3.90 \mathrm{a}$ & $3.92 \mathrm{a}$ & $4.05 a$ & $4.05 a$ & $4.09 \mathrm{a}$ & \\
\hline
\end{tabular}

Remarks: Means followed by the same uppercase letter in the same column and by the same lowercase letter in the same row are not significantly different according to DMRT at $5 \%$.

Recommended dose of organic fertilizer (cow manure): $30 \mathrm{~kg} \mathrm{plant}^{-1}$

Table 5. The Weight of Fresh Fruit Bunches Per Plant as Affected by Mycorrhizae Inoculation and Cow Manure Doses

\begin{tabular}{lcccccc}
\hline \multirow{2}{*}{ Mycorrhizae } & \multicolumn{4}{c}{ Cow manure (percentage of recommended doses fertilizer for oil palm) } & Mean \\
\cline { 2 - 5 } & 0 & 25 & 50 & 75 & 100 & \\
\hline Without inoculation & $27.83 \mathrm{c}$ & $27.67 \mathrm{c}$ & $32.17 \mathrm{~b}$ & $35.83 \mathrm{ab}$ & $46.60 \mathrm{a}$ & 34.02 \\
With inoculation & $\mathrm{A}$ & $\mathrm{B}$ & $\mathrm{B}$ & $\mathrm{B}$ & $\mathrm{B}$ & $\mathrm{B}$ \\
& $28.33 \mathrm{c}$ & $34.50 \mathrm{~b}$ & $53.17 \mathrm{a}$ & $52.00 \mathrm{a}$ & $50.60 \mathrm{a}$ & 43.72 \\
\hline Mean & $\mathrm{A}$ & $\mathrm{A}$ & $\mathrm{A}$ & $\mathrm{A}$ & $\mathrm{A}$ & $\mathrm{A}$ \\
\hline
\end{tabular}

Remarks: Means followed by the same uppercase letter in the same column and by the same lowercase letter in the same row are not significantly different according to DMRT at $5 \%$.

Recommended dose of organic fertilizer (cow manure): $30 \mathrm{~kg} \mathrm{plant}^{-1}$

mycorrhizae inoculation can improve the growth and yield of oil palm. Therefore, mycorrhizae can save the use of cow manure by $50 \%$ of the recommended dose. Based on those results, it is proven that arbuscular mycorrhiza fungi (AMF) can support the growth and yield of oil palm as well as increase the ability of plants to absorb more nutrients from soil solution. Mycorrhizae hyphae can facilitate the plant to absorb water and nutrients. Mycorrhizal colonization (Table 6) increases the absorption of water and nutrients. Several researches (Same, 2011; Ortas and Akpinar, 2011;
Bhattacharjee and Sharma, 2012; Ortas, 2012; Zhang et al., 2012; Kathlee and Treseder, 2013; Watts-Williams Stephanie, et al., 2014; Lu et al., 2015; Binu et al., 2015; İncesu et al., 2015; Liu et al., 2015) also reported that AMF (Arbuscular Mycorrhizae Fungi) had the ability to promote plants growth and yield by enhancing absorption of macro nutrients, especially phosphate and some micro elements.

AMF is an alternative technology to support growth and to improve productivity and quality of crops primarily grown on ultisols. AMF can 
Table 6. The Percentage of Oil Palm Root Infection as Affected by Mycorrhizae Inoculation and Cow Manure Doses

\begin{tabular}{ccccc}
\hline & & \multicolumn{3}{c}{ Percentage of oil palm root infection } \\
\cline { 3 - 5 } No. & Treatments & 4 & Months after transplanting (MAT) \\
\cline { 3 - 5 } & & 1.33 & 15 & 1.33 \\
\hline 1. & $\mathrm{M}_{0} \mathrm{P}_{0}$ & 0.67 & 1.33 & 1.33 \\
2. & $\mathrm{M}_{0} \mathrm{P}_{1}$ & 1.33 & 1.67 \\
3. & $\mathrm{M}_{0} \mathrm{P}_{2}$ & 1.67 & 1.67 & 1.67 \\
4. & $\mathrm{M}_{0} \mathrm{P}_{3}$ & 1.33 & 1.67 & 2.33 \\
5. & $\mathrm{M}_{0} \mathrm{P}_{4}$ & 2.33 & 2.33 & 100.0 \\
6. & $\mathrm{M}_{1} \mathrm{P}_{0}$ & 100.0 & 100.0 \\
7. & $\mathrm{M}_{1} \mathrm{P}_{1}$ & 100.0 & 100.0 \\
8. & $\mathrm{M}_{1} \mathrm{P}_{2}$ & 98.33 & 100.0 & 100.0 \\
9. & $\mathrm{M}_{1} \mathrm{P}_{3}$ & 100.0 & 100.0 & 100.0 \\
\hline
\end{tabular}

Remarks: M: Mycorrhizae inoculation

$M_{0}$ (without mycorrhizae inoculation). $M_{1}$ (with mycorrhizae inoculation)

$\mathrm{P}$ : The percentage of cow manure dose from recommended doses of fertilizer for oil palm.

$P_{0}$ (without cow manure), $P_{1}\left(25 \%=7.25 \mathrm{~kg} \mathrm{plant}^{-1}\right), \mathrm{P}_{2}\left(50 \%=15 \mathrm{~kg} \mathrm{plant}^{-1}\right), \mathrm{P}_{3}\left(75 \%=22.5 \mathrm{~kg} \mathrm{plant}^{-1}\right), \mathrm{P}_{4}\left(100 \%=30 \mathrm{~kg} \mathrm{plant}^{-1}\right)$

Recommended dose of organic fertilizer (cow manure): $30 \mathrm{~kg} \mathrm{plant}^{-1}$

colonize root system by generating direct benefits for the host plants. They can improve nutrient uptake, especially phosphate (Same, 2011; Ortas and Akpinar, 2011; Bhattacharjee and Sharma, 2012; Ortas, 2012; Kathlee and Treseder, 2013; Watts-Williams Stephanie et al., 2014), improve plant resistance to abiotic stresses (Zhu et al., 2012) and heavy metal stress (Krishnamoorthy et al., 2015), and protect palm oil from stem rot disease (Simanjuntak et al., 2013).

Organic fertilizer from cow manure combined with mycorrhizae inoculation can increase plant growth, yield and levels of $\mathrm{N}, \mathrm{P}, \mathrm{K}$ and $\mathrm{Mg}$ in the leaves of oil palm grown on ultisol. This is due to the organic fertilizer (cow manure) that can improve the physical, chemical and biological properties of the soil (Tampubolon and Hendriansya, 2011) and Gomes et al. (2014). The roots of plants inoculated with mycorrhizae are protected from pathogen attack. The plants are physically protected by the hyphae, which produce hormones and growth regulators for plants (Hahn et al., 1999)

The application of mycorrhizae to the soil can improve soil structure (Leifheit et al., 2014) and trigger growth regulator substances (auxin, cytokinin, and gibberellin). Plant growth regulators are needed in the process of cells division, which stimulate growth and prevent or slow the aging process thereby increasing root function to absorb nutrients and water (Auge, 2001).

The structure of mycorrhizae on the plant roots can increase the area for metabolic exchange between the host plant and mycorrhizae. AMF can also absorb organic phosphate and convert it into inorganic $\mathrm{P}$ that can be absorbed by plants with the help of acid phosphatase enzyme. Accordingly, acid phosphatase enzyme produced by fungal hyphae is currently active, hence developing and enhancing the activity of phosphatases on the root surface. Mycorrhizae fungi release inorganic phosphate from organic phosphates in the area near the surface of the cell so that it can be absorbed through the mechanism of nutrient uptake (Gunawan, 1983). Phosphorus is one of the macro nutrients that are important in plant growth and development. The element serves as a constituent metabolite in complex compounds, as activator, and as enzyme cofactors or unifying fibers. It also plays a role in 
physiological processes as structural component of several important compounds and in molecular energy transfer of ADP and ATP (Gardner et al., 1991; Marschner 1997).

ATP compounds is an important compound for metabolite reactions, which is the reaction of the biosynthetic formation of compounds essential for the maintenance and growth of cells, including proteins and nucleic acids. In addition, ATP is required for the synthesis of food reserves, such as lipids and polysaccharides. It is also needed in the process of active transport and flow of protoplasm. Phosphorus is an element that is critical for plant growth, where the $\mathrm{P}$ deficiency leads to inability of plants to absorb other elements. As an important element in the formation of energy for plant growth, sufficient $\mathrm{P}$ will improve plant growth. If the energy is available in sufficient quantity, all the metabolic processes can occur properly. The effects of AMF on plant growth were caused by the increase in absorption of nutrients by the larger surface area of absorption or the ability to mobilize sources of nutrients that are not easily available. AMF have a very important function for plant growth, primarily due to increased absorption of P (Prawiranata et al., 1992).

\section{CONCLUSIONS}

The combination of indigenous mycorrhizae and cow manure could improve oil palm growth and yield. Oil palm treated with mycorrhizae inoculation and cow manure doses of $50 \%$ of recommended dose fertilizer could increase the growth, yield component, and yield of oil palm.

\section{ACKNOWLEDGEMENTS}

Great thanks are addressed to the Directorate General of Research, Technology and Higher Education for the funding through the Higher Education Research Grant under the Contract Number: 16 / UN21.6 / LT / 2016.

\section{REFERENCES}

Augé, R.M. 2001. Water relations, drought and vesicular-arbuscular mycorrhizal symbiosis. Mycorrhiza 11: 3-42

Bhattacharjee. S., G. D. Sharma. 2012. Effect of Dual Inoculation of Arbuscular Mycorrhiza and Rhizobium on the Chlorophyll, Nitrogen and Phosphorus Contents of Pigeon Pea (Cajanus cajan L.). Adv Microbiol 2: 561-564.

Binu N.K., P.K. Ashokan and M. Balasundara. 2015. Influence of Different Arbuscular Mycorrhizal Fungi and Shade on Growth of Sandal (Santalum album) Seedlings. Journal of Tropical Forest Science 27(2): 158-165

Gardner, F. P., Pearce, R. B., dan Mitchael. 1991. Fisiologi Tanaman Budidaya. Universitas Indonesia: Jakarta.

Gomes, M.P., M. L. Andrade, C. C. Nascentes and M.R. Scotti. 2014. Arsenic Root Sequestration by a Tropical Woody Legume as Affected by Arbuscular Mycorrhizal Fungi and Organic Matter: Implications for Land Reclamation. Water Air Soil Pollut 225:1919, doi.org/10.1007/s11270-014-1919-8.

Gunawan, A.W. 1993. Mikoriza arbuskula. PAU Ilmu Hayat. IPB. Bogor.

Hahn. A.C.1999. Immunochemical Properties of Mycorrhizas. Mycorrhizae: Structure Function. Molecular Biology and Biotechnology. Springer-Verlag. Berlin.

Incesu. M.. T. Yesiloglu. B. Cimen. B. Yilmaz. C. Akpinar. I. Ortas. 2015. Effects on Growth of Persimmon (Diospyros virginiana) Rootstock of Arbuscular Mycorrhizal Fungi Species. Turk. J. Agric. For. 39: 117-122

Kartika. E. 2012. Peranan Cendawan Mikoriza Arbuskular dalam Meningkatkan Daya Adaptasi Bibit Kelapa Sawit terhadap Cekaman Kekeringan pada Media Tanah Gambut. Jurnal Bioplantae. Volume I No.2: 52-63.

Krishnamoorthy. R.. Chang-Gi Kim. P. Subramanian. Ki-Yoon Kim. G. Selvakumar. Tong-Min Sal. 2015. Arbuscular Mycorrhizal Fungi Community Structure. Abundance and Species Richness Changes in Soil by Different Levels of Heavy Metal and Metalloid Concentration Plos One 2:1-15 | DOl:10.1371/journal. pone.0128784 June 2. $2015: 1-15$

Leifheit. E.F.. D. Stavro.s Veresoglou. A. Lehmann. E. K. Morris. and M. C. Rillig. 2014. Multiple Factors Influence the Role of Arbuscular Mycorrhizal Fungi in Soil Aggregation-a meta-analysis. Plant Soil 374:523-537.

Liu. H.. M. Yuan. S. Tan. X. Yang. Z. Lan and Q. Jiang. 2015. Enhancement of Arbuscular Mycorrhizal Fungus (Glomus versiforme) on the Growth and Cd uptake by Cd-Hyper Accumulator Solanum Nigrum. Applied Soil Ecology 89: 44-49.

Lu. N.. X. Zhou, M. Cui, M. Yu, J. Zhou, Y. Qin and Y. Li. 2015. Colonization with Arbuscular Mycorrhizal Fungi Promotes the Growth of Morus alba L. Seedlings Under Greenhouse Conditions. Forests 6: 734-747

Marschner H. 1997. Mineral nutrition of higher plant. Univ. Academic Press. Inc. San Diego. 889p.

Ortas. I. 2012. The effect of Mycorrhizal Fungal Inoculation on Plant Yield. Nutrient Uptake and Inoculation Effectiveness under Longterm Field Conditions. Field Crop Res 125: 35-48.

Ortas. I. and C. Akpinar. 2011. Response Of Maize Genotypes To Several Mycorrhizal Inoculums In Terms Of Plant Growth. Nutrient Uptake And Spore Production. J. Plant Nutr. 34: 970-987. 
Prawiranata WS, Harran S, Tjondronegoro P. 1992. Dasar-dasar fisiologi tumbuhan. Jilid I. Jur. Biologi. Fak. Matematika dan IPA. IPB.

Refliaty, G. Tampubolon dan Hendriansyah. 2011. Pengaruh Pemberian Kompos Sisa Biogas Kotoran Sapi Terhadap Perbaikan Hasi Kedelai (Glycine Max (L.) Merill). J. Hidrolitan. Vol. 2:103-114.

Same. M. 2011. Serapan Phospat dan Pertumbuhan Bibit Kelapa Sawit pada Tanah Ultisol Akibat Cendawan Mikoriza Abuskular. Jurnal Penelitian Pertanian Terapan Vol. 11 (2): 69-76.

Simanjuntak. D. Fahridayanti dan A. Susanto. 2013. Efikasi Mikoriza dan Trichoderma sebagai Pengendali Penyakit Busuk Pangkal Batang (ganoderma) dan Sebagai Pemacu Pertumbuhan di Pembibitan Kelapa Sawit. Widyariset. Vol. 16 (2) : 233-242.

Steel R. G. D. and Torrie, J.H. 1980. Principles and Procedures of Statistics. McGraw-Hill, Inc.

Watts-Williams, J. Stephanie, T. Turney, W. Patti, A. F. Cavagnaro T. R. 2014. Uptake of Zinc and Phosphorus by Plants is Affected by Zinc Fertilizer Material and Arbuscular Mycorrhizas. Plant Soil 376:165-175.

Zhang. T., N. Shi. D. Bai. Y. Chen. and G. Feng. 2012. Arbuscular Mycorrhizal Fungi Promote the Growth of Ceratocarpus arenarius (Chenopodiaceae) with No Enhancement of Phosphorus Nutrition. Plos One 7: 1-8

Zhu XC., F. B. Song FB. Liu SQ. Liu TD. Zhou X (2012). Arbuscular Mycorrhizae Improves Photosynthesis and Water Status of Zea mays L. Under Drought Stress. Plant Soil Environ 58: 186-191. 